\title{
Performance of rearing female hoggets under different feeding strategies
}

\author{
Felipe Jochims ${ }^{1}$, Cleber Cassol Pires ${ }^{2}$, Alexandre Lins ${ }^{3}$, Luana Cortez Zago ${ }^{3}$, Guilherme \\ Mello Jahn ${ }^{3}$, Anna Carolina Cerato Confortin ${ }^{4}$
}

\footnotetext{
1 Programa de Pós-Graduação em Zootecnia, UFRGS, RS.

2 Departamento de Zootecnia, CCR/UFSM, RS.

${ }^{3}$ Graduação em Zootecnia, UFSM, RS.

${ }^{4}$ Programa de Pós-Graduação em Zootecnia, UFSM, RS
}

ABSTRACT - The objective of this study was to evaluate the performance of Texel $\times$ Ile de France female hoggets on pearl millet (Pennisetum americanum (L.) Leeke) pastures fed supplementation with cassava meal or corn gluten. It was used a completely randomized experimental design, with three treatments (feed strategies) and two area replications. Feed strategies consisted of supplementation of the pastures with cassava meal or corn gluten in comparison to exclusive pasture. Supplements were given daily at 9:00 a.m. at quantity of $1 \%$ of the body weight (BW). The lambs on corn gluten supplementation presented greater daily weight gain and greater per area weight gain. Use of supplementation did not permit to increase pasture stocking rate, however. In vitro digestibility and chemical composition of the harvested forage was similar (crude protein, neutral detergent fiber) among groups. At the end of the experiment, all feed strategies were efficient in promoting weight greater than $60 \%$ of the mature weight, showing that the lambs are able for mating. Body condition score (BCS) of lambs under cassava meal supplementation was 3.0 whereas body composition score of the other lambs was 2.8. Exclusive use of pearl millet can provide dry matter requirement of the lambs.

Key Words: average daily gain, body condition score, cassava meal, corn gluten meal, mature weight, Pennisetum americanum (L.) leeke

\section{Desempenho de cordeiras na recria submetidas a diferentes estratégias alimentares}

RESUMO - Este estudo foi realizado para avaliar o desempenho de cordeiras Texel $\times$ Ile de France em pastagem de milheto (Pennisetum americanum (L.) Leeke) recebendo suplementação com farinha de mandioca ou glúten de milho. O delineamento experimental foi inteiramente casualizado, com três tratamentos (estratégias alimentares) e duas repetições de área. As estratégias alimentares consistiram da suplementação da pastagem com farinha de mandioca ou glúten de milho em comparação à pastagem exclusiva. Os suplementos foram fornecidos diariamente, às $9 \mathrm{~h}$, em quantidade equivalente a $1 \%$ do peso vivo (PV). As cordeiras sob suplementação com glúten de milho apresentaram maior ganho de peso diário e por área. A utilização de suplementos, no entanto, não permitiu aumentar a taxa de lotação da pastagem. A digestibilidade in vitro e a composição bromatológica da forragem colhida foi semelhante (proteína bruta, fibra em detergente neutro) entre os grupos. Ao final do experimento, todas as estratégias alimentares foram eficientes para promover pesos superiores a $60 \%$ do peso adulto, indicando que as cordeiras estão aptas para o início do encarneiramento. O escore de condição corporal (ECC) das cordeiras sob suplementação com farinha de mandioca foi de 3,0, enquanto o das demais foi 2,8. O uso exclusivo de pastagem de milheto é capaz de suprir as exigências de matéria seca de cordeiras.

Palavras-chave: escore de condição corporal, farinha de mandioca, ganho médio diário, glúten de milho, peso adulto, Pennisetum americanum (L.) leeke

\section{Introduction}

Because sheep creation shows a price recovery and market stabilization, which increase the profitability, sheep production has become a good alternative for producers in recent years (Viana \& Souza, 2007). According to Simplicio et al. (2003), the lamb meat consumption has increased; however, due to the limited product supply, up to $80 \%$ of Brazilian consumption is provided with imported meat from Mercosul and New Zealand.

In order to overcome this meat demand, the growing phase of the hoggets becomes fundamentally important for improving the production system. Sheep production in Rio Grande do Sul is based on natural pasture, which often 
does not meet the requirements of lambs in the growing phase as for example dry matter intake. These requirements are high, and it is likely that lambs do not achieve $60 \%$ of their mature weight at eight months of age in order to reach puberty and be mated (Sá \& Sá, 2003).

The inclusion of cultivated pastures in a production system is an option designed to maintain high yields of dry matter and forage quality, allowing increase in weight gain inasmuch as it supplies the requirements of DM intake of animals, enabling lambs to be mated early. In addition, pasture is the cheapest source of nutrients for ruminants (Carvalho et al., 1999). Pearl millet (Pennisetum americanum (L.) Leeke) is a good alternative to improve the feeding of lambs. Castro (2002) has observed weight gains of $121.7 \mathrm{~g} /$ day on lambs consuming pearl millet.

Supplementation has also been suggested as a feeding strategy to improve animal performance. The use of energy supplements aims to improve the ruminal utilization of the pasture nitrogen, both increasing the ruminal microbial protein production and enhancing energy supply and metabolizable protein intake (Poppi \& McLennan, 1995). The supply of low degradability protein concentrate may lead to an increase in the supply of metabolizable protein, providing better animal performance (Mayne \& Peyraud, 1996).

Thus, the objective of this work was to evaluate the performance of crossbred Texel $\times$ Ile de France lambs in the rearing phase, grazing pearl millet pasture, receiving or not receiving supplements.

\section{Material and Methods}

The study was conducted at Universidade Federal de Santa Maria (UFSM), in the Departamento de Zootecnia, from November $6^{\text {th }}, 2006$ to March $28^{\text {th }}, 2007$. The area is located in the physiographic region called Central

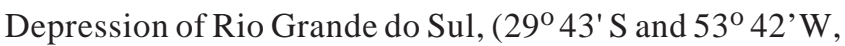
$95 \mathrm{~m}$ of altitude). The climate is humid subtropical (Cfa), according to Köppen classification (Moreno, 1961).

The experimental design was completely randomized, with two area replicates and three treatments, as follows: M - animals only in pearl millet pasture (Pennisetum americanum (L.) Leeke); CM-animals in pearl millet pasture and supplemented with cassava meal at a ratio of $1 \%$ of body weight (BW); and GL - animals in pearl millet pasture and supplemented with corn gluten meal (protenose), at the proportion of $1 \%$ of body weight.

Pearl millet sowing ( $50 \mathrm{~kg} / \mathrm{ha}$ of seeds) was performed on November 6, 2006 by using conventional tillage (planting). The fertilizer application was $200 \mathrm{~kg} / \mathrm{ha}$ of
5-20-20 (N-P-K) formula, and topdressing was $135 \mathrm{~kg} / \mathrm{ha}$ of nitrogen, as urea, divided into three applications (02/02/07; 02/27/07; 03/15/07). The experimental area had 0.8 ha divided into six experimental units with about 0.14 ha, plus an area of 0.3 ha to forage mass regulator animals. The experiment was divided into three periods (January $3^{\text {rd }}, 2007$ to February, $14^{\text {th }}$ 2007; February $17^{\text {th }}, 2007$ to March $17^{\text {th }}, 2007$ and March $7^{\text {th }}, 2007$ to March 28 $\left.{ }^{\text {th }}, 2007\right)$ with 21 days each, totaling 63 days of continuous grazing.

It was used four ewe lamb per replicate, a total of eight test animals per treatment, all products from the crossing of Texel and Ile de France ewes, at $177 \pm 12$ days of age and initial weight of $30.2 \pm 2.6 \mathrm{~kg}$, respectively. The Haemonchus contortus infestation of animals was monitored by the FAMACHA method (Malan \& Van Wick, 1991) every 10 days, and control was performed when necessary.

The animals were submitted to a period of 18 days for adaptation to the supplements. During the experiment, lambs were supplemented daily in individual stalls, where they remained for 50 minutes, at 9 a.m., as recommended by Medeiros et al. (2007).

The grazing method used was continuous stocking with a variable number of regulator animals to keep the forage mass at $2000 \mathrm{~kg} / \mathrm{DM}$ ha. The stocking rate adjustment was done every 10 days, according to Heringer \& Carvalho (2002). Grazing period was of 24 hours, and all animals had unrestricted access to water, mineral supplementation, and natural shadow.

The forage mass, in kg/dry matter per ha, was estimated every 10 days by using direct visual estimation double sampling technique (Mannetje, 2000), with five cuts close to the ground and 20 visual estimations per experimental unit. The forage from the cuts was homogenized and divided into two sub-samples, one for determining the dry matter content of the pasture, and another for the botanical and morphological separation of its components. These samples were weighed and dried in an oven with forced air at $55^{\circ} \mathrm{C}$ for at least 72 hours until they reached constant weight. Through the manual separation of the morphological components of the pasture, the percentage of leaf blades, stems and sheaths, and the relationship blade/stem + sheath (leaf/stem ratio) were determined. Forage mass multiplied by the percentage of pasture green material resulted in green forage mass. The leaf blades mass was obtained by multiplying the forage mass by the leaf blades percentage in the pasture. The daily dry matter herbage accumulation was assessed by using three cages of grazing exclusion for experimental unit.

The female hogget weight performance was measured every 21 days, with 12 hours of total fasting. In these 
occasions, the body condition score of the animals was also evaluated, by the transverse processes of the lumbar spines palpation. These assessments were performed by three previously trained people, and the same evaluators did the ratings until the end of the experiment. Scores ranged from 1 (very thin) to 5 (very fat), and intermediate values were considered in increments of 0.5 points. For the analysis, mean values of the treatments were used, which could have resulted in broken values. The average daily gain was calculated as the difference between the final average weight and initial average weight of test animals, divided by the number of days among weighings. The calculation of body weight gain per area was performed by subtracting the final weight of the initial weight of test animals and adding the difference to the gain value of the regulator animals when they were grazing.

The stocking rate, expressed in $\mathrm{kg} / \mathrm{ha}$ of body weight, was obtained by adding the average weight of the test animals, adding to this value the average weight of the regulator animals, multiplied by the number of days which they remained in the experimental units, divided by the number of days in the period.

The forage offer ( $\mathrm{kg}$ of DM to $100 \mathrm{~kg} \mathrm{BW}$ ) was obtained by dividing daily forage availability (forage mass / number of days of the period + daily herbage accumulation) by stocking rate, and then multiplying it by 100 . The green leaf blades offer was obtained by multiplying the percentage of forage offer by leaf percentage in the pasture.

The collect of the forage apparently consumed by grazing animals was performed by trained evaluators who observed test animals grazing in the paddocks (Euclides et al., 1992). Samples were weighed, dried in an oven at $55^{\circ} \mathrm{C}$ for 72 hours, and grounded in Wiley type mill with a 1-mm sieve for laboratorial testing and determination of crude protein by Kjeldahl method (AOAC, 1995), in vitro organic matter digestibility (Tilley \& Terry, 1963), and neutral detergent insoluble fiber (Van Soest et al., 1991).

Data were statistically analyzed by variance analysis and F-test, including interaction between treatments $x$ periods to all collected variables. When there was a difference among the means, the Tukey test at a significance level of 5\% using GLM procedure was applied. Data were analyzed using the SAS statistical package (2001), version 8.2.

\section{Results and Discussion}

There was no treatment $\times$ periods interaction $(\mathrm{P}>0.05)$ for forage mass, green forage mass, mass of green leaf blades, other species herbage mass and daily herbage accumulation (Table 1 ).

During the experiment, animals were submitted to similar pasture conditions in the alternative scenarios of grazing, and there was no difference $(\mathrm{P}>0.05)$ among feed strategies or periods for forage mass, green forage mass, mass of green leaf blades and daily herbage accumulation (Table 1). Lambs were subjected to an average forage mass at $2451 \mathrm{~kg} / \mathrm{DM}$ ha during the trial period. According to Rattray et al. (1987), tropical grass pastures with forage mass greater than $1,800 \mathrm{~kg} / \mathrm{DM}$ ha do not limit lambs consumption of pasture.

Total pasture dry mass production is dependent on daily herbage accumulation values found during the trial period, so the pasture production did not differ $(\mathrm{P}>0.05)$ among feeding strategies. Daily herbage accumulation values are similar to values found by Castro (2002), working with sheep in pearl millet pasture, and to those

Table 1 - Pearl millet pasture characteristics and daily herbage accumulation, in kg/DM ha

\begin{tabular}{|c|c|c|c|c|c|}
\hline & Forage mass & Green forage mass & Green leaf mass & Other species mass & Daily herbage accumulation \\
\hline \multicolumn{6}{|l|}{ Feed strategies } \\
\hline Cassava meal & 2646 & 2329 & 672 & 1024 & 103 \\
\hline Corn gluten meal & 2530 & 2153 & 478 & 1069 & 91 \\
\hline Pearl millet & 2177 & 1860 & 439 & 956 & 93 \\
\hline $\mathrm{F}$ & 0.87 & 0.97 & 0.93 & 0.27 & 0.67 \\
\hline $\mathrm{P}$ & 0.4500 & 0.4150 & 0.4309 & 0.7715 & 0.5335 \\
\hline \multicolumn{6}{|l|}{ Periods (days) ${ }^{1}$} \\
\hline $1-21$ & 2699 & 2352 & 688 & 1060 & 110 \\
\hline $22-43$ & 2228 & 1915 & 445 & 942 & 88 \\
\hline $43-64$ & 2425 & 2076 & 456 & 1046 & 87 \\
\hline $\mathrm{F}$ & 0.82 & 0.85 & 1.12 & 0.34 & 2.44 \\
\hline $\mathrm{P}$ & 0.4722 & 0.4595 & 0.3675 & 0.7195 & 0.1421 \\
\hline \multicolumn{6}{|l|}{$\mathrm{T} \times \mathrm{P}$ interaction ${ }^{2}$} \\
\hline F & 0.14 & 0.12 & 0.40 & 1.07 & 0.46 \\
\hline $\mathrm{P}$ & 0.9627 & 0.9734 & 0.8052 & 0.4269 & 0.7627 \\
\hline $\mathrm{CV}(\%)^{3}$ & 26.12 & 27.81 & 60.02 & 26.57 & 21.97 \\
\hline
\end{tabular}

${ }^{1}$ Periods 1,2 , and 3 , respectively; ${ }^{2}$ Treatment $\times$ periods interaction; ${ }^{3}$ Coefficient of variation. 
found by Elejalde et al. (2010), evaluating lamb performance in pearl millet.

There was no treatment $\times$ periods interaction and no difference $(\mathrm{P}>0.05)$ in leaf/stem ratio, stocking rate, forage offer, and green leaf blade offer in the different feeding strategies and different periods of the pasture use (Table 2). Values are similar to those found by Montagner (2002). The stocking rate and forage offer showed difference $(\mathrm{P}<0.05)$ in different periods of utilization due to the handling of regulator animals in order to follow the experimental protocol. Values of stocking rate are similar to those reported by Castro (2002) and Schwartz et al. (2003), in their work with sheep in pearl millet pastures.

Despite the numerical difference, the average daily gain (ADG) was not different $(\mathrm{P}>0.05)$ during the evaluation periods , mainly because of the high coefficient of variation from data (Table 3$)$. However, there are differences $(\mathrm{P}<0.05)$ in ADG in period means. Animals fed corn gluten meal presented an average daily gain $54 \%$ higher $(\mathrm{P}<0.05)$ when compared to the gains of hoggets supplemented with cassava meal and $82 \%$ higher than those values obtained by not supplemented animals. The hoggets without supplements and the animals which were given cassava meal showed no performance differences $(\mathrm{P}>0.05)$.

Female hoggets supplemented with corn gluten meal had average daily gains values similar to those found in the literature (Grande et al. 2003); however, the performance of not supplemented animals was lower than values observed by Castro (2002), and similar to those reported by Montagner (2002), working with female hoggets in a pearl millet pasture.

There was a difference $(\mathrm{P}<0.05)$ for the total weight gain. Female hoggets supplemented with corn gluten meal have a bigger total gain, when compared with the hoggets supplemented with cassava meal and animals which were not supplemented. These two groups showed a similar total weight gain to each other $(\mathrm{P}>0.05)$, and they showed gains on average 36 and $45 \%$ lower than those supplemented with corn gluten meal, respectively. There was a difference $(\mathrm{P}<0.05)$ among the three groups for gain per area. The animals supplemented with corn gluten meal presented a higher $(\mathrm{P}<0.05)$ area gain, followed by the hoggets supplemented with cassava meal and, at last, the animals kept only in the pasture.

Table 2 - Leaf/stem ratio, stocking rate (kg/ha BW), forage offer (kg DM/100kg BW), and green leaf blade offer (GLBO, kg DM/100 kg $\mathrm{BW}$ ) in pearl millet pasture

\begin{tabular}{|c|c|c|c|c|}
\hline & Leaf/Stem & Stocking rate & Forage offer & GLBO \\
\hline \multicolumn{5}{|l|}{ Feed strategies } \\
\hline Cassava meal & 1.02 & 1698 & 15.2 & 2.2 \\
\hline Corn gluten meal & 0.77 & 1607 & 14.5 & 1.5 \\
\hline $\mathrm{F}$ & 2.16 & 0.23 & 0.11 & 0.81 \\
\hline $\mathrm{P}$ & 0.1711 & 0.8013 & 0.9010 & 0.4750 \\
\hline \multicolumn{5}{|l|}{ Periods (days) ${ }^{1}$} \\
\hline $22-43$ & 0.78 & $977 b$ & $19.9 \mathrm{a}$ & 2.2 \\
\hline $43-63$ & 0.78 & $1365 b$ & $19.5 a$ & 1.5 \\
\hline $\mathrm{F}$ & 2.54 & 19.06 & 12.24 & 1.04 \\
\hline $\mathrm{P}$ & 0.1335 & 0.0006 & 0.0027 & 0.3934 \\
\hline \multicolumn{5}{|l|}{$\mathrm{T} \times \mathrm{P}$ interaction ${ }^{2}$} \\
\hline $\mathrm{F}$ & 0.31 & 0.51 & 0.55 & 0.68 \\
\hline
\end{tabular}

Values followed by different lowercase letters in the same column differ $(\mathrm{P}<0.05)$ by Tukey test.

${ }^{1}$ Periods 1,2 , and 3 , respectively; ${ }^{2}$ Treatment $\times$ periods interaction.

Table 3 - Average daily gain in different periods and period means, total weight gain (kg), and gain per area (gain/ha) of hoggets in pearl millet pasture

\begin{tabular}{|c|c|c|c|c|c|c|}
\hline & Period 1 & Period 2 & Period 3 & Periods mean & Total gain & Gain/ha \\
\hline \multicolumn{7}{|l|}{ Feed strategies } \\
\hline Cassava meal & 0.108 & 0.074 & 0.103 & $0.096 b$ & $5.7 \mathrm{~b}$ & $182 b$ \\
\hline Corn gluten meal & 0.116 & 0.155 & 0.134 & $0.133 a$ & $8.9 a$ & $250 a$ \\
\hline CV $(\%)^{1}$ & 29.42 & 34.35 & 43.65 & 21.76 & 21.75 & 2.41 \\
\hline
\end{tabular}

Values followed by different letters in the same column differ $(\mathrm{P}<0.05)$ by Tukey test.

${ }^{1}$ Coefficient of variation. 
These observed values of organic matter in vitro digestibility (OMIVD), crude protein (CP), and neutral detergent fiber (NDF) (Table 4) of the pasture indicate that pearl millet is a medium quality forage pasture, because the found values are lower than values observed in pastures of high quality, such as ryegrass (Medeiros et al., 2007). Despite the inferior quality of pearl millet pasture, when compared with ryegrass pastures, according to NRC (1985), this pasture is able to meet the nutritional requirements for growing lambs with moderate gains.

Hoggets ingested grass with similar in vitro digestibility and chemical composition (NDF and crude protein) $(\mathrm{P}>0.05$ ), demonstrating that the supplementation does not change the selection strategy and seizure of grazing lambs. Values of diet composition, NDF and in vitro digestibility suffered change $(\mathrm{P}<0.05)$ during grazing periods due to the pasture increasing age (Maraschin, 1979).

There were differences in crude protein concentration among periods $(\mathrm{P}<0.05)$, and this result is probably due to a difference in the time of collection of samples in hand plucking evaluation. Samples of the first and third periods of evaluation were collected in the early morning (8:00 to 10:00 a.m.), and samples of the second period were collected in the late afternoon (4:00 to 6:00 p.m.), which may have caused the reduction of $\mathrm{CP}$ proportion on hand pluck samples of the second period. This occurs because at the end of the day animals are less selective in their diet, in order to meet their demands of dry matter intake, thus reducing the concentration of crude protein from consumed grass (Medeiros et al,. 2007).

The different performances of the animals submitted to different feeding strategies (Table 3) can be explained by differences in the composition of supplements that are used to feed the animals (Table 5).

According to Poppi \& McLennan (1995), the supply of readily fermentable carbohydrates (cassava meal) can improve animal performance through a better use of grass consumed nitrogen by increasing ruminal protein production and supply of energy to animals.

In this experiment, there was a difference $(\mathrm{P}<0.05)$ among the supplemented groups; however, no differences ( $\mathrm{P}>0.05$ ) were found in average daily gain (period means) and in the total weight gain (Table 3) between animals maintained on treatment with supply of cassava meal and the animals kept exclusively on pearl millet pasture. The similar result of these two feeding strategies (pasture + cassava meal $\times$ only pasture) may probably be explained by median levels of nitrogen found in the hand plucking sample, which was not enough for an increase in ruminal protein production.

Table 4 - Organic matter in vitro digestibility, neutral detergent fiber (NDF), and crude protein of consumed grass by hoggets, in periods and feeding strategies

\begin{tabular}{|c|c|c|c|}
\hline & In vitro digestibility (\%) & NDF (\%) & Crude protein (\%) \\
\hline \multicolumn{4}{|l|}{ Feed strategies } \\
\hline Cassava meal & 58.7 & 57.2 & 17.1 \\
\hline Corn gluten meal & 58.3 & 58.3 & 16.8 \\
\hline Pearl millet & 54.7 & 59.3 & 16.6 \\
\hline $\mathrm{F}$ & 3.13 & 1.42 & 0.18 \\
\hline $\mathrm{P}$ & 0.0929 & 0.2915 & 0.8392 \\
\hline \multicolumn{4}{|l|}{ Periods $\left(\right.$ days) ${ }^{1}$} \\
\hline $1-21$ & $60.7 \mathrm{a}$ & $55.3 b$ & $17.9 \mathrm{a}$ \\
\hline $22-43$ & $55.7 b$ & $59.7 a$ & $14.5 b$ \\
\hline $43-64$ & $55.3 b$ & $59.7 \mathrm{a}$ & $18.0 \mathrm{a}$ \\
\hline $\mathrm{F}$ & 5.67 & 8.15 & 10.90 \\
\hline $\mathrm{P}$ & 0.0255 & 0.0096 & 0.0039 \\
\hline \multicolumn{4}{|l|}{$\mathrm{T} \times \mathrm{P}$ interaction ${ }^{2}$} \\
\hline $\mathrm{F}$ & 1.21 & 1.53 & 0.67 \\
\hline $\mathrm{P}$ & 0.3694 & 0.2722 & 0.6262 \\
\hline $\mathrm{CV}(\%)^{3}$ & 5.37 & 3.75 & 8.76 \\
\hline
\end{tabular}

Values followed by different lowercase letters in the same column differ by Tukey test $(\mathrm{P}<0.05)$.

${ }^{1}$ Periods 1 , 2, and 3 , respectively; ${ }^{2}$ Treatment $\times$ periods interaction; ${ }^{3}$ Coefficient of variation.

Table 5 - Dry matter content, crude protein, organic matter in vitro digestibility, and neutral detergent fiber (NDF) in the supplements

\begin{tabular}{lcccc}
\hline Supplements & \multicolumn{4}{c}{ Parameters } \\
\cline { 2 - 5 } & Dry matter (\%) & Crude protein (\%) & In vitro digestibility & NDF (\%) \\
\hline Cassava meal & 92 & 8.40 & 0.89 & 7.68 \\
Corn gluten meal & 93 & 63.41 & 0.55 & 21.30 \\
\hline
\end{tabular}


The supply of corn gluten meal showed higher weight gain $(\mathrm{P}<0.05)$ of hoggets due to nutritional increased support provided by the supplementation with undegradable protein in the rumen. This occurs because corn gluten meal has a high content of crude protein, with low degradability (59\%), supplying both protein requirements of lambs for a further shift of protein from the diet directly into the small intestine and energy requirements of lambs through the transformation of excess of protein into glucose (Kozlosky, 2002).

During the experimental period, lambs kept exclusively on pearl millet pasture showed an increase of $7.7 \%$ of their initial experimental weight, and at the end of the trial period they reached $62.7 \%$ of their adult weight. Supplemented animals obtained more weight evolution: supplementation with cassava meal provided an $11 \%$ gain, and the hoggets reached $67.0 \%$ of their mature weight at the end of the experiment. Also, the supplementation with corn gluten meal provided a $15 \%$ gain from the beginning of the experiment, and at the end of the experimental period, hoggets kept in this feeding strategy reached $68.0 \%$ of adult weight. According to Sá \& Sá (2003), female hoggets only reach the puberty and are able to mate when they obtain weights $60 \%$ greater than their mature weight.

In addition, Ribeiro et al. (2003) explained that animals must arrive to the mating season featuring a body condition score 2.5 to 3.5 to avoid an injury in pregnancy rate. The body condition score for test animals of corn gluten meal feeding strategy did not change $(\mathrm{P}>0.05)$ during the evaluation period (Table 6 ), whereas the body condition score of lambs fed cassava meal and lambs kept only grazing decreased $(\mathrm{P}<0.05)$ during the experimental period.

There was no difference $(\mathrm{P}>0.05)$ for body condition score among feeding strategies, and at the end of the experimental period, animals showed an appropriate value for the start of mating. Guerreiro et al. (1994) has confirmed that feeding strategies compound with ad libitum pasture, with moderate gains of about $100 \mathrm{~g} /$ day, appear sufficient to ensure the development of body structure and mammary gland for lambing at 12-14 months. Nevertheless, according to Back \& Davis (1994) and Susin (1996), body condition score of female hoggets should be around 3.0 in the arrival of breeding season, preventing negative effects in their future milk production by fat deposition in mammary glands.

Table 6 - Female hoggets body condition score during experimental period in pearl millet pasture

\begin{tabular}{|c|c|c|c|c|}
\hline & \multicolumn{2}{|c|}{ Body condition scores } & \multirow[t]{2}{*}{ Mean } & \multirow[t]{2}{*}{$\mathrm{CV}(\%)^{3}$} \\
\hline & Initial measure ${ }^{1}$ & Final measure ${ }^{2}$ & & \\
\hline \multicolumn{5}{|l|}{ Feed strategies } \\
\hline Cassava meal & $3.3 \mathrm{aA}$ & $2.8 \mathrm{~B}$ & 3.0 & 10.91 \\
\hline Corn gluten meal & 2.9ab & 2.8 & 2.8 & 13.14 \\
\hline Pearl millet & $3.1 \mathrm{bA}$ & $2.6 \mathrm{~B}$ & 2.8 & 9.82 \\
\hline Mean & $3.1 \mathrm{~A}$ & $2.7 \mathrm{~B}$ & 2.8 & 11.59 \\
\hline $\mathrm{CV}(\%)^{3}$ & 8.99 & 13.77 & 12.96 & - \\
\hline
\end{tabular}

Values followed by different lowercase letters in the same column differ $(\mathrm{P}<0.05)$ by Tukey test.

Values followed by different uppercase letters in the same line differ $(\mathrm{P}<0.05)$ by Tukey test.

${ }^{1}$ Measures collected in evaluations on January, $3^{\text {rd }} 2007 ;{ }^{2}$ Measures collected in evaluations on March $28^{\text {th }} 2007 .{ }^{3}$ Coefficient of variation.

\section{Conclusions}

The utilization of corn gluten meal offers higher individual gains, as well a higher gain per area, but all feed alternatives used in this study are able to provide adequate development of the female hoggets, which at the end of the experiment showed weights over $60 \%$ of mature weight. Among food alternatives evaluated here, the exclusive use of pearl millet pasture is indicated, because it is able to meet the requirements of dry matter intake of lambs in the growing phase without the costs related to the supplements.

\section{References}

ASSOCIATION OF OFFICIAL ANALITICAL CHEMISTRY AOAC. Official methods of analysis. 16.ed. Arlington: AOAC International, 1995. 1025p.

CARVALHO, P.C.F.; PRACHE, S.; DAMASCENO, J.C. O processo de pastejo: desafios da procura e apreensão da forragem pelo herbívoro. In: REUNIÃO ANUAL DA SOCIEDADE BRASILEIRA DE ZOOTECniA, 36., 1999, Porto Alegre. Anais... Porto Alegre: SBZ, 1999. p.253-268.

BECK, N.F.G.; DAVIES, M.C.G. The effect of stage of breeding season or pre-mating oestrogen and progestagen therapy on fertility in ewe lambs. Animal Production, v.59, p.429-434, 1994.

CASTRO, C.R.C. Relações planta-animal em pastagem de milheto (Pennisetum clandestinum (L.) Leeke) manejadas em diferentes alturas com ovinos. 200f. 2002. Dissertação 
(Mestrado em Zootecnia) - Universidade Federal do Rio Grande do Sul, Porto Alegre.

ELEJALDE, D.A.G.; ROCHA, M.G.; BREMM, C. et al. Desempenho de cordeiras em pastagem de azevém e de milheto sob suplementação. Revista Brasileira de Zootecnia, v.39, n.4, p.707-715, 2010.

EUCLIDES, V.P.B.; MACEDO, M.C.M.; OLIVEIRA, M.P. Avaliação de diferentes métodos de amostragens sob pastejo. Revista Brasileira de Zootecnia, v.21, n.4, p.691-702, 1992.

GUERREIRO, C.D.; BELO, A.T.; PEREIRA, M.S. et al. Effect of the nutritional level on the development of the mammary gland in Serra da Estrela ewe-lambs. Revista Portuguesa de Ciências Veterinárias, v.100, p.553-558, 1994.

GRANDE, P.A.; ALCALDE, C.R.; MACEDO, F.A.F. et al. Desempenho e características de carcaça de cabritos da raça Saanen recebendo ração com farelo de glúten de milho e/ou farelo de soja. Acta Scientiarum. Animal Science, v.25, n.2, p.315-321, 2003.

HERINGER, I.; CARVALHO, P.C.F. Ajuste da carga animal em experimentos de pastejo: uma nova proposta. Ciência Rural, v.32, n.4, p.675-679, 2002.

KOZLOSKI, G.V. Bioquímica dos ruminantes. Santa Maria: Universidade Federal de Santa Maria, 2002. v.1. 140p.

MALAN, F.S.; VAN WYCK, J.A. The packed cell volume and color of the conjunctivae as aids for monitoring Haemonchus contortus infestations in sheep. In: BIENNIAL NATIONAL VETERINARY CONGRESS, 1., 1992, Grahamstown, África do Sul. Anais... Grahamstown: South African Veterinary Association, 1991. v.1. p.139.

MANNETJE t', L. Measuring biomass of grassland vegetation. In: MANNETJE, L.t'; JONES, R.M. (Eds.) Field and laboratory methods for grassland and animal production research. Cambridge: CABI, 2000. p.151-178.

MARASCHIN, G.E. Potencial produtivo de gramíneas forrageiras de verão no sul do Brasil. Lavoura Arrozeira, v.32, n.315, p.18-24, 1979.

MAYNE, C.S.; PEYRAUD, J.L. Recent advances in grassland utilization under grazing and conservation. In. GRASSLAND AND LAND USE SYSTEMS, 16., 1996, Grado, Italy. Proceedings... Grado, Italy: European Grassland Federation Meeting, 1996. p.347-360.

MEDEIROS, R.B.; PEDROSO, C.E.S.; JORNADA, J.B.J. et al. Comportamento ingestivo de ovinos no período diurno em pastagem de azevém anual em diferentes estádios fenológicos. Revista Brasileira de Zootecnia, v.36, n.1, p.198-204, 2007.
MONTAGNER, D.B.; ROCHA, M.G.; PILAU, A. et al. Desempenho de borregas em pastejo rotativo com milheto. In: REUNIÃO ANUAL DA SOCIEDADE BRASILEIRA DE ZOOTECNIA, 39. 2002, Fortaleza. Anais... Fortaleza: SBZ, 2002. (CD-ROM).

Moreno, J.A. Clima do Rio Grande do Sul. Porto Alegre: Secretaria da Agricultura, 1961. 41p.

NATIONAL RESEARCH COUNCIL - NRC. Ruminant nitrogen usage. Washington, D.C.: National Academy Press, 1985. 138p.

POPPI, D.P.; McLENNAN, S.R. Protein and energy utilization by ruminants at pasture. Journal of Animal Science, v.73, p.278-290, 1995

RATTRAY, P.V.; THOMPSON, K.F.; HAWKER, H. et al. Pastures for sheep production. In: NICOL, A.M. (Ed). Livestock feeding on pasture. Hamilton: New Zealand Society of Animal Production, 1987. p.89-104.

RIBEIRO, L.A.O.; FONTANA, C.S.; WALD, V.B. et al. Relação entre a condição corporal e a idade das ovelhas no encarneiramento com a prenhez. Revista Ciência Rural, v.33, n.2, p.357-361, 2003.

SÁ, C.O; SÁ, J.L. Influência no manejo reprodutivo na oferta de cordeiros para o abate. In: SIMPÓSIO MINEIRO DE OVINOCULTURA, 3. 2003, Lavras. Anais... Lavras: Universidade Federal de Lavras, 2003. p.80-101.

SCHWARTZ, F.; ROCHA, M.G.; VÉRAS, M. et al. Manejo de milheto (Pennisetum americanum Leeke) sob pastejo de ovinos. Revista Brasileira de Agrociência, v.9, n.2, p.151-155, 2003.

SIMPLÍCIO, A.A.; WANDER, A.E.; LEITE, E.R. A caprinoovinocultura de corte como alternativa para a geração de emprego e renda. Sobral: Embrapa Caprinos, 2003. 44p. (Documentos online 48). Disponível em: <http:// www.cnpc.embrapa.br/DOC48.pdf>. Acesso em: 3/3/2007.

STATISTICAL ANALYSIS SYSTEM - SAS. User's guide. Version 8.2 Cary: Statistical Analysis System Institute, 2001. (CD-ROM).

SUSIN, I. Exigências nutricionais de ovinos e estratégias de alimentação. In: SILVA SOBRINHO, A.G.; BATISTA, A.M.V. et al. (Eds.) Nutrição de ovinos. Jaboticabal: FUNEP, 1996. p.119-141.

TILLEY, J.M.A.; TERRY, R.A. A two-stage technique for the in vitro digestion of forage crop. Journal of British Grassland Society, v.18, n.2, p.104-111, 1963.

VAN SOEST, P.J.; ROBERTSON, J.B.; LEWIS, B.A. Methods for dietary fiber, neutral detergent fiber, and nonstarch polysacharides in relation to animal nutrition. Journal of Dairy Science, v.74, p.3583-3597, 1991.

VIANA, J.G.A.; SOUZA, R.S. Comportamento dos preços dos produtos derivados da ovinocultura no Rio Grande do Sul no período de 1973 a 2005. Ciência Agrotécnica, v.31, n.1, p.191-199, 2007. 